\title{
O poder e suas representações no interior das comunidades agregas do Vale do Mucuri, Minas Gerais (1850-1950)
}

Power and its representations within the agricultural communities of the Mucuri Valley, Minas Gerais (1850-1950)

Márcio Achtschin Santos ${ }^{1}$

\begin{abstract}
Resumo
O objetivo desse artigo é analisar as representações formadas a partir das relações de poder nas comunidades de agregados do Vale do Mucuri, região do nordeste do estado de Minas Gerais, entre o final do século XIX e meados do século XX. A questão é de que modo se estabeleceu a vida política nesses grupos e como essas relações de poder são representadas, tendo como referência o rito da Folia de Reis. A metodologia adotada foi entrevistas semiestruturadas e periódicos da região do Mucuri do período. Como resultado da pesquisa pode-se apontar que o poder no agrego estabelecia nas práticas e vivências do cotidiano, em redes de solidariedade do dia a dia. A Folia de Reis se tornou um ritual político de reforço àqueles que viviam na escassez, mobilizando e legitimando as regras de convivência a partir da ajuda mútua.
\end{abstract}

Palavras-chave: Vale do Mucuri; Comunidade agrega; poder; Imaginário Social; Folia de Reis.

\begin{abstract}
The purpose of this article is to analyze the representations formed from the power relations in the communities of agregados, in the Mucuri Valley, a region in the northeast of the state of Minas Gerais, between the end of the 19th century and the mid-20th century. The question of how political life is established in these groups and how these power relations are represented, taking as a reference the Folia de Reis rite. The methodology adopted was semi-structured interviews and periodicals from the Mucuri region of the period. As a result of the research, it can be pointed out that power in the aggregate established in everyday practices and experiences, in solidarity networks of everyday life. The Folia de Reis became a political ritual to reinforce those who lived in scarcity, mobilizing and legitimizing the rules of coexistence based on mutual aid.
\end{abstract}

Keyworks: Mucuri Valley; community agrega; power; Social Imaginary; Folia de Reis.

\section{Introdução}

Em um Brasil que apenas recentemente se tornou majoritariamente urbano, ainda são escassas as pesquisas que analisam as expressões políticas construídas no meio rural. Penetrar nesses sertões e parte de sua representação política é o desafio que esse trabalho se presta, pois trata das relações de poder no agrego, no Vale do Mucuri, região do nordeste do estado de Minas Gerais, entre o final do século XIX e meados do século XX.

\footnotetext{
${ }^{1}$ Doutorado em História pela Universidade Federal de Minas Gerais, Brasil (2013). Professor Assistente da Universidade Federal dos Vales do Jequitinhonha e Mucuri, Brasil. E-mail: márcio.achtschin@ufvjm.edu.br
} 
Buscar reflexões em torno das representações da sociedade agrega já se justificaria por si só, pois há uma lacuna enorme envolvendo esse tema. Fértil também é a oportunidade de analisar comunidades nas quais as relações de poder não atuam exclusivamente dentro de uma lógica ocidentalizada, ou seja, que relacionam política de forma exclusiva com o Estado e pelo comportamento racional.

Estudos das representações e culturas políticas realizadas nas últimas décadas têm trazido leituras fundamentais para análise nas diversas áreas das ciências humanas. No entanto, ainda que as propostas e as tentativas ocorrem no intuito de resgatar elementos para esses estudos, as bases teórico-metodológicas ainda dificultam uma nova perspectiva analítica. Isso porque duas tendências ainda são determinantes para esses estudos: 1) a base das relações políticas ter como fundamento a ação racional; 2) e a análise política estar presa exclusivamente ao Estado.

Apesar da historiografia ter ampliado o leque de atores na formação da sociedade brasileira, ainda se preserva o modelo de política relacionado ao Estado, apresentando uma análise de mão única: dominantes e dominados. Aponta para uma leitura vertical na qual exclui outras formas de poder, de grupos aparentemente pouco participativos (e consequentemente pouco agraciados) nas vantagens envolvendo iniciativa pública.

Por sua vez, as pesquisas desenvolvidas no campo das representações políticas ainda têm como forte tendência a privilegiar uma lógica da ação motivada pela racionalidade. A base da produção do conhecimento a partir da modernidade encontrou na ação racional uma sustentação segura para analisar a política. O que não estava incluso ao comportamento racional nos jogos de poder acabou sendo negligenciado pela pesquisa.

Nesse campo das representações, a racionalidade conduz frequentemente para o ideológico. Seguindo essa tendência, as abordagens mais frequentes são pesquisas em torno das representações envolvendo o republicanismo, fascismo, jacobinismo, democracia etc. Ainda que pertinentes em alguns casos, essas explicações, normalmente construídas através de uma perspectiva racional, dificulta e/ou limita o entendimento em situações que exigem a aplicação de outras formas de representações. Especialmente como em algumas situações no Brasil, distante das experiências políticas europeias ou norte-americanas, locais que herdaram esse modelo.

No caso dos grupos agregos do Mucuri, a busca nesse trabalho é identificar as relações de poder do agregado e suas representações políticas no interior dessas comunidades. Isso se faz visível através dos ritos, pois este torna “. . . certos aspectos do 
mundo social mais presente do que outros . . Minha posição é a de que o rito, como o mito, consegue colocar em close up as coisas do mundo social" (DAMATTA, 1990, p. 63-64). Nesse ambiente, os rituais festivos são os que mais corroboram, pois são manifestações contundentes dessa relação de poder. É o caso da Folia de Reis, ritual expressivo no meio rural da região.

Assim, as questões postas seriam: Como agregados do Vale do Mucuri se perceberiam no seu espaço e de que modo se estabelece relações de poder com outros ao seu redor? De que maneira os ritos reiteram as representações políticas no agrego? De que modo é construído o imaginário para o reconhecimento e permanência dessas relações de poder?

Foi considerado como campo de pesquisa a antiga Mesorregião do Vale do Mucuri, localizada no nordeste de Minas Gerais. Esse recorte espacial se justifica, pois o município de Teófilo Otoni se emancipou em 1878 e correspondeu ao longo do recorte temporal, utilizado nesse artigo, tal território. Essa opção deve-se também ao fato de ter os jornais de Teófilo Otoni disponíveis como fontes, que publicavam informações de todas as regiões do Mucuri.

Para atender os objetivos propostos, o artigo se divide em 3 partes: a primeira discute as bases teórico-metodológicas utilizadas para analisar o poder e as representações entre os agregados. Em seguida, apresenta as atividades agregas no Vale do Mucuri, o modo de vida e as regras de convivência dos agregados na região, pois, reconhecer as relações de poder na sociedade agrega passa pela identificação e as condições de vida de seus atores, do ambiente que vivem e das diversas formas que se relacionam entre si. Por fim, na última parte, é analisado as suas representações construídas a partir das relações de poder no agrego, trabalhando a partir do rito da Folia de Reis.

\section{Poder e representações como base teórico-metodológicas}

O que se propõe como base teórica nesse estudo é uma análise na qual seja possível perceber a existência da política além e apesar do Estado. Originando o motivo de buscar o oder $^{2}$ como categoria e não a política para analisar as relações existentes, em especial nesse ambiente recortado pelo agrego no Vale do Mucuri. A proposta teórica que

\footnotetext{
${ }^{2}$ Nesse estudo, por poder se entende o uso da força, mesmo que não se faça uso dela, mas que tenha capacidade de influir na conduta de outros, conforme KAPLAN, Abraham. LASSWELL, Harold. Poder e Sociedade. Brasília: Editora Universidade de Brasília, 1979. LEBRUN, Gérard. O que é poder. São Paulo: Brasiliense, 2004. STOPPINO, Mario. Poder. In Dicionário de Política. BOBBIO, Norberto. MATTEUCCI, Nicola. PASQUINO, Gianfranco. Brasília: Editora Unviersidade de Brasília, 1998.
} 
privilegia o poder como categoria favorece uma flexibilidade muito maior de percepção na relação de forças em um ambiente de comunidade ou grupos regionais.

Tornam assim visíveis grupos que vivem às margens da vida política, em suas próprias construções de poder, dando autonomia a segmentos excluídos e suas estratégias, que tanto pode tensionar como aproximar de grupos dominantes. A partir desse entendimento, o poder é exercido no seu cotidiano e por múltiplos atores. Incorporado à política macro, mas também micro, pois é no território (não necessariamente espaços demarcados fisicamente) e as suas relações específicas a referência para uma análise mais segura acerca desse poder.

As variações temporais e suas especificidades regionais apontam vivências que assumem nas relações humanas a segurança através do controle do outro. Não se propõe nessa pesquisa ignorar ações racionais nas relações de poder, mas buscar um alargamento nas análises políticas, pois, segundo Girardet,

Com algumas exceções, e essas exceções são recentes, todas tendem a
restringir sua exploração ao domínio exclusivo do pensamento organizado,
racionalmente construído, logicamente conduzido . . . Tudo o que escapa às
formulações demonstrativas, tudo o que brota das profundezas secretas das
potências oníricas permanece, de fato, relegado a uma zona de sombra, na qual
bem raros são aqueles que ousam penetrar (GIRARDET, 1987, p. 9-10).

Nesse aspecto, o poder e as suas múltiplas representações agem por diversos interesses e arranjos no mundo do cotidiano, em realidades múltiplas de ações na vida pública que não são essencialmente racionais, ou, se o são, ganham especificidades que distanciam dos padrões utilitaristas e planejados dentro de uma lógica ocidental.

Em comportamentos identificados no imaginário, no mito, no símbolo, no ícone, o poder tem uma lógica própria. Essas representações carregam um forte carga afetiva e emocional. Francisco Falcon (2000) considera que as representações correspondem a uma elaboração da consciência cognitiva humana ao mundo externo. Segundo Falcon, tanto pode ser uma releitura do que está presente como fazer presente a partir de uma reapresentação do que está ausente. É o caso do imaginário.

O imaginário, segundo Laplantine e Trindade (1997), é uma representação fundamentada em imagens construídas socialmente. Está diretamente relacionada com a realidade, mesmo que não seja sua tradução exata, uma vez que refaz ou reconstrói esse real. Ou seja, é a percepção de uma realidade exterior reconstruindo as imagens: "O imaginário, portanto, de maneira geral, é a faculdade originária de pôr ou dar-se, sob a forma de apresentação de uma coisa, ou fazer aparecer uma imagem e uma relação que não são dadas diretamente na percepção" (LAPLANTINE; TRINDADE, 1997, p. 24). 
A realidade, como elemento físico, é preservada, mas o imaginário, não sendo um mero reprodutor, faz uma interpretação das imagens existentes criando novas relações interpretativas a partir do sujeito e em relação ao objeto. Apesar de não negar o real, o transfigura, criando novas percepções dentro de uma forma particular de compreender o mundo, carregada de fato e de emoções. O imaginário se compõe através de forte apelo emocional, como sonhos, princípios morais, desejos etc. Isso não quer dizer que no imaginário, com seu caráter afetivo, haja a ausência da razão, mas ocorre um afastamento de raciocínio lógico como condutor ou justificador de suas ações, distanciando do conceito como o de ideologia.

De acordo com Bronislaw Backzo (1985), imaginário e poder estão entrelaçados. Há uma função de multiplicidade e complexidade no uso das representações coletivas no poder político, onde o imaginário assume um importante e diversificado papel, quer seja no uso dessas representações como forma de legitimar o poder ou da recusa dessa dominação. O imaginário social é um aspecto de uma coletividade, no qual se elaboram representações próprias que respondem a conflitos, tensões e consensos.

O poder precisa do imaginário como forma de se legitimar. A reação, do mesmo modo, precisa de construções imaginárias para por em causa o poder estabelecido. $\mathrm{O}$ poder se estabelece e se conserva através de ". . dispositivos extremamente variados e bem 'reais' de proteção, senão de repressão, com vista a assegurar-se do lugar privilegiado no domínio dos imaginários sociais" (BACZKO, 1985, p. 310). Ainda de acordo com Baczko, um exemplo mais visível para as mobilizações do imaginário pode ser dado quando ocorrem ataques externos a uma comunidade, no qual se utilizam intensas energias dos membros invadidos em favor da autodefesa.

Os sistemas simbólicos mais estáveis tornam-se motivações para existência e ação dos grupos sociais, operando no imaginário social a partir das experiências somadas a desejos, temores, esperanças etc. Há no imaginário social a construção de símbolos que asseguram a um grupo social interpretações diversas e complexas, propondo uma adesão de sistemas de valores, levando o indivíduo a ações comuns e construindo modelos de comportamento no qual “...suas funções são múltiplas: designar o inimigo no plano simbólico; mobilizar as energias e representar as solidariedades; cristalizar e ampliar os temores e esperanças difusos.” (BACKZO, 1985, p. 316). Essas representações, sendo forças que regulam a vida coletiva, produzem identidades que delimitam territorialidades ambientais ou representativas, formando alianças e rivalidades. 
Para Roger Chartier (1990), os discursos e suas representações, inclusive o imaginário, ao serem analisados, necessariamente devem ter relação direta com o seu recorte temporal e espacial, estabelecidos pelos interesses dos grupos envolvidos no estudo. Chartier entende ainda que essas representações são legitimadoras de um projeto, traduzindo posições e interesses de grupos que pensam a sociedade a sua maneira ou o modo como a idealizam, dentro de um processo histórico definido, superando o caráter universalizante e trans-histórico dado pela fenomenologia.

\section{O Vale do Mucuri e as atividades agregas}

O Vale Mucuri, até meados do século XIX, era uma terra habitada por comunidades indígenas em grupos heterogêneos. Longe da exploração aurífera dos anos de 1700, pois o governo português queria manter as matas da região para ser um obstáculo natural das práticas do contrabando. Esse quadro mudou no século seguinte.

Para Cunha (2002), a ocupação mineira no século XIX esteve relacionada com o crescimento populacional que supera os limites das áreas mineradoras com muita mercantilização e o seu nível de desenvolvimento se entrelaçava com bases produtivas diferenciadas e em dinâmicas particularizadas (RIBEIRO, 2013). A produção cafeeira se estabeleceu ao longo da segunda metade dos anos de mil e oitocentos e foi determinante para formação da sociedade regional. Com a Crise de 1929 e o enfraquecimento do café como produto no mercado, a pecuária se tornou a principal produção agrícola da região do Mucuri. Tendo como base econômica a agropecuária, a principal mão-de-obra utilizada foi o agrego, tanto na lavoura quanto na criação do gado (ACHTSCHIN, 2018).

O trabalho agrego foi implantado no Brasil a partir do período colonial, sendo uma atividade de homens livres realizada concomitante com o trabalho escravo (FRANCO, 1974). Mas, já findando a escravidão, o agrego aumentou, ganhando vigor ao longo do século XIX em regiões onde o trabalho escravo perdia fôlego. Se em São Paulo, Rio de Janeiro e parte de Minas Gerais mudou o formato produtivo com a presença imigrante, o agregado continuou nos sertões, caso do nordeste mineiro.

O regime agrário denominado agregação pode ser entendido como a cessão da terra por parte do fazendeiro ao indivíduo ou família que tinha direito a extração das matas e o uso da terra. Em troca, trabalhava temporadas para a fazenda ${ }^{3}$. O agregado era aquele que

\footnotetext{
${ }^{3}$ Sobre o agrego, ver: RIBEIRO (2010). ASSIS ( 2007). FRANCO (1974). LINHART (2002). MARTINS (1981). QUEIROZ (1976). SUAREZ (1982).
} 
utilizava a terra para produzir alimentos e extração de matérias-primas, mas não era o proprietário. Por não ter a posse, tinha parte da terra cedida pelo proprietário de terra para ser explorada (MACHADO, 2006). De acordo com Eduardo Ribeiro (2013), o agregado destinava parte do tempo no trabalho da fazenda e outra parte na sua roça. $\mathrm{O}$ trato mais comum, ainda que variasse de acordo com as especificidades locais e temporais, era a cessão da terra para a lavoura, a derrubada da mata liberada, além da caça, pesca e coleta.

À medida que o Estado se fortaleceu e conseguiu maior controle no Vale do Mucuri, a partir dos anos de 1970, fazendo vigorar as leis trabalhistas no campo, o agrego desapareceu na região. Também contribuiu para o fim desse tipo de trabalho o esgotamento das matas e o fortalecimento de movimentos sociais na zona rural com o processo de abertura democrática dos anos 80 .

O agrego foi determinante para a formação do Vale do Mucuri, compondo o cenário rural das médias e grandes propriedades por, aproximadamente, um século. Para Eduardo Ribeiro, “...poucos lugares em Minas Gerais tiveram presença e mantiveram lembranças tão fortes da agregação quanto o Jequitinhonha e o Mucuri. Ser agregado ou ter agregados fez parte da vida de quase todas as famílias desses lugares" (RIBEIRO, 2013). O trabalho agrego chegou com os proprietários vindos especialmente do Vale do Jequitinhonha a partir da segunda metade do século XIX.

Os grupos que compuseram o trabalho agrego na região do Mucuri era muito diverso. Em comum, a condição de serem despossuídos da propriedade rural. Basicamente eram os sobreviventes indígenas que perderam suas reservas, gradativamente enquadrados no mundo do trabalho das lavouras; os ex-escravos, que mantiveram-se no mesmo local onde foram cativos; os ex-posseiros, que não tinham recursos para o próprio sustento ou por pressão do latifundiário para abandonar a sua terra. Por fim, os retirantes vindos da região norte em condições precárias. O periódico “O Mucury” de 01 de outubro de 1899, afirmava que " não passa um só dia sem que magotes de famílias atravessam a região [...] dez e mais pessoas [...] que se internam pelas matas [grifo nosso]"4.

\section{A sobrevivência nas comunidades agregas do Vale do Mucuri}

Em 01 de novembro de 1941, o jornal "O Norte de Minas" noticiou o crime de envenenamento por "pó de Joanes" cometido por Josefa Soares dos Santos contra seu companheiro agregado e os quatro filhos na zona rural do distrito de Águas Belas [atual

\footnotetext{
${ }^{4}$ Jornal O Mucury - 01.10.1899-p. 03.
} 
município de Águas Formosas]. O motivo: "pôr fim à miséria em que viviam seu marido e filhos"

As condições de vida nas comunidades agregas do Mucuri era de precariedade extrema. De acordo com o depoimento do entrevistado "J", "O que a gente recebia era uma mixaria, 'comparadamente' um dia de trabalho dava pra comprar uma lata de óleo de segunda qualidade ou uma medida de feijão". Em uma fazenda com 50 famílias de agregados, podia contar, em média, com 500 trabalhadores disponíveis a uma remuneração baixíssima. O poder de escolha entre tantos trabalhadores era muito favorável ao ruralista. $\mathrm{O}$ entrevistado " $\mathrm{C}$ " relatou que "tinha um fazendeiro da região que dizia que empregado era igual vara de coqueiro, perdeu um você 'vai' no mato e acha outro".

Nas atividades realizadas para o fazendeiro na lavoura o agregado era o plantador e colhedor de café, feijão ou milho. Na pecuária, fazia-se cerca, marcava o gado, roçava pasto. Concomitante a esses serviços, o agregado chegava para a fazenda para a derrubada, quer seja para o futuro pasto, quer seja para ampliar o latifúndio ocupando as terras devolutas.

O tempo de trabalho que o agregado realizava para o fazendeiro era diverso, não há um padrão ou modelo estabelecido que obedecesse uma rotina comum no labor. Em terras onde as atividades eram muitas, na qual havia uma grande produção, trabalhava-se de forma regular de segunda-feira a sábado, com folga no domingo. Alguns dos depoimentos chegam a relatar trabalhos ao longo de todos os sete dias da semana. Quando a atividade na fazenda era esporádica, o tempo para a produção própria do agregado era maior. Mas nem todos conseguiam produzir para si. As terras destinadas à produção agrega eram de baixa qualidade e não havia recurso para aquisição de insumos.

No tempo que sobrava ao agregado, procurava trabalhar na lavoura para seu consumo. O espaço para o plantio era definido pelo fazendeiro, longe da grande lavoura ou do pasto: “Trabalhar 'pra' nós, a roça era em uma chapada lá em cima. Tinha aqui lugar bom de lavoura, mas a gente tinha de ir lá 'pra' aquele inferno. Aqui perto de nós não podia" (entrevistada “G”). Era nesse dia que a família tinha tempo para dedicar às atividades para o consumo próprio, e, em alguns casos produzir excedente para a venda. Em um espaço comum cedido pelo fazendeiro, normalmente se dividia entre os agregados o local de

\footnotetext{
${ }^{5}$ Jornal O Norte de Minas - 01.11.1941 - p. 02.
} 
plantio de cada família. O plantio era o milho, o arroz, o feijão e a mandioca. Em algumas situações, o agregado criava galinha e porco.

As condições de vida das comunidades agregas eram desoladoras. O representante do Instituto Mineiro do Café, Ormêo Junqueira Botelho, em artigo escrito no "O Norte de Minas” constatava que, na zona rural “...as endemias como a bouba, impaludismo e o amarelão são impressionantes" (O Norte de Minas, 22.02.1935). As epidemias devastavam populações inteiras no Vale do Mucuri. $\mathrm{O}$ acesso a qualquer atendimento médico era difícil, as fazendas ficavam a quilômetros de um centro urbano com uma estrutura mínima. A realidade do agrego no Vale do Mucuri é muito distante da literatura na qual apresenta o coronel como recurso para atendimento médico dos camponeses, em um "leva e traz" compensado pelas barganhas políticas. No nordeste mineiro, não se tinha qualquer assistência do fazendeiro, como relatou o entrevistado " $\mathrm{D}$ ": "Quando adoecia, não tinha hospital, se virava na roça mesmo. O patrão nem queria saber da vida do agregado".

Carência também em objetos de uso pessoal. A roupa, por exemplo, era um objeto raro. O entrevistado " $F$ " afirma que "Muitas vezes, a roupa era de saco de estopa". Segundo o entrevistado "I", "A vestimenta era única, vivia-se de remendo sobre remendo". O calçado era outra necessidade de difícil aquisição para os agregados, o comum era andar descalço.

\section{$O$ agrego e o seu modo de preservar a vida}

Grande parte de objetos de uso era retirado da mata que o agregado vinha para derrubar. Do relato na confecção da cama feito pelo entrevistado "C", no Médio Mucuri, ilustra bem esses recursos: "As camas eram umas esteiras de taboa. Ninguém tinha colchão naquela época, era feita de taboa. As camas, 'enficavam' duas forquilhas, amarravam de vara, ia no mato, tecia a taboa e fazia o colchão". A construção da moradia também era a partir do que a natureza poderia dispor: "As casas eram feitas pelo próprio agregado. Era feita de "enxumento". "Envarela" a parede e bate barro, cobrindo com "tabinha" ou rebuçada com capim. Com capim era mais comum, colocada bem em pé, bem caído a cobertura, de modo que não entrava água" (entrevistado "D”).

Onde não se tinha acesso a hospitais, nem a médicos e nem a remédios, os recursos para o tratamento com a saúde eram a partir do espaço de vivências e convivências. A autonomia das comunidades agregas na preservação da vida pode ser verificado desde o nascimento dos bebês. As parteiras eram figuras centrais na geração de novas vidas. Foi 
consensual na resposta de todos os entrevistados que em gerações anteriores, nas suas e dos seus filhos, ocorriam apenas partos feitos no ambiente doméstico e com parteira: "Naquela época tudo era na roça, eu nasci de parteira. Meus irmãos nasceram tudo na roça com a mesma parteira" (entrevistado " $F$ ").

A mata era a principal fonte para produção de medicamentos: "para tratar de saúde, o povo nesse tempo se salvava mais à base de Deus e remédio no mato" (entrevistado "N"). Estava no conhecimento da mata e suas propriedades os recursos para medicar, quer seja uma dor de ouvido, quer seja picada de cobra. Desse modo, tão importante quanto as propriedades das raízes e folhas, era a sabedoria do como e quando ser usado.

As crenças povoaram o universo agrego, especialmente no isolamento que viviam. A imensidão da mata estimulava mistérios e magias que nem é dado a todos o poder de decifrar. Muito presente no cotidiano agrego, os valores cristãos ganhavam entendimentos próprios, em uma religiosidade reconstruída dentro do próprio espaço de convivência. Desses poderes de cura mais brandos fundados em bases católicas, como quebrantos e mau-olhado, as rezadeiras intervinham. Mas para intervir em enfermidades de maior gravidade o curador era chamado. Além de suas rezas, era a garrafada o medicamento para cura das moléstias. As informações da flora do Mucuri e o uso das plantas medicinais apontam para a presença indígena no meio agrego e sua forte influência no cotidiano dessas comunidades. Um desses males mais frequentes nas fazendas era a picada de cobra, e contra elas o antídoto para se salvar era trazido da mata. O uso das folhas e raízes, bem como as rezas, ficava a cargo do curador.

Ainda que em tom crítico, a fama de alguns desses homens de cura na zona rural não passava despercebida pela imprensa do Mucuri. O periódico “O Norte de Minas" de 06 de janeiro de 1945 anunciou a morte de Joaquim, denominado pelo jornal como curandeiro, atingindo “...as almas rudes e ingênuas de nossos campônios"6. Ainda de acordo com o semanário, Joaquim “...inoculava nos rudes cérebros dos roceiros a ideia e a crença no sobrenatural, da cura por artifício"7 . Segundo a publicação, Joaquim ganhou fama como curador, atuando em sua casa na roça, utilizando raízes e conhecimento da medicina “...indígena e a virtude de suas drogas" 8 .

\footnotetext{
${ }^{6}$ Jornal O Norte de Minas - 06.01.1945 - p. 03.

${ }^{7}$ Jornal O Norte de Minas - 06.01.1945 - p. 03.

${ }^{8}$ Jornal O Norte de Minas - 06.01.1945 - p. 03.
} 


\section{As relações de poder e suas representações entre os agregados}

Quanto às relações de poder, em um ambiente de brutalidade e força entre quem tem e quem não tem posse, tensões e conflitos permanentes também seriam a norma entre os agregados. Essa foi, inclusive, uma tendência apresentada pelos pesquisadores do agrego, sendo a violência uma referência moral para a convivência nessas comunidades (QUEIROZ, 1976).

Mas é preciso contar com outras variantes, caso das condições de extrema precariedade no Vale do Mucuri, a ausência do Estado e o isolamento, o que deu uma lógica própria ao jogo de poder nas comunidades agregas. Uma das unanimidades nos depoimentos apresentou um quadro inteiramente inverso, apontando para um espaço de convivência no qual predominava a cooperação entre os grupos familiares agregados: "A violência vinha dos fazendeiros, a convivência entre os agregados era boa" (entrevistado "E").

As comunidades que viviam do trabalho agrego do Vale do Mucuri estabeleceram sua relação de poder a partir da ajuda mútua. Na ausência ou baixa competitividade entre quem não possui propriedade, no distanciamento do Estado e consequente abandono, as comunidades no agrego tenderam à manutenção da vida pela solidariedade. Foi voz única nas entrevistas: "Na convivência entre os agregados não existia conflito. Não existia. Era todo mundo unido" (entrevistado “C”).

Assim, torna-se visível que o poder no caso do agrego se estabelecia pelo domínio de grupo. As relações de poder ocorriam em um ambiente ausente de espaço público, dotado de direitos e deveres muito próprios, através de uma integração entre os ambientes domésticos das comunidades agregas que se intercambiavam em um emaranhado de dependências materiais e espirituais.

Esses laços de solidariedade se formavam e se fortaleciam nos ambientes de convivência comuns (mas não públicos) na zona rural. Dentre esses vínculos de partilha, pode ser citada a ajuda mútua entre os agregados no plantio e colheita de suas produções. Em um sistema de mutirão alternado, a comunidade se dedicava de forma coletiva no espaço produtivo do outro. Chamada de "troca do dia", se tornou uma prática socialmente obrigatória, consolidada e instituída entre os agregados de todas as regiões do Vale do Mucuri: "um trabalhava para o outro cinco dias, depois ia pra terra do outro e trabalhava mais cinco dias" (entrevistado "M").

Essas partilhas realizadas em rede de favores se consolidaram, ocorrendo no cotidiano de modo ritualístico. Entre elas, a divisão das partes do porco por toda a vizinhança, 
chamada de "dar um fresco". Essa prática esteve presente nas diversas falas de agregados em regiões de distâncias extremas em todo Mucuri. Segundo a entrevistada "U”, "a filharada saia levando de casa em casa pedaços do porco. Quando o outro matava um carneiro, do mesmo jeito. Eu era pequena e ia com meus irmãos levando nas casas o quarto de leitoa 'pra' um, um pedaço 'pra' outro”. Rito descrito também pelo entrevistado "D": "Havia muita amizade. Quando um matava uma leitoa, dividia com a vizinhança. Aí quando o vizinho matava, fazia do mesmo jeito. Eles falavam era 'dar um fresco"”.

Não se deve imaginar nessa reciprocidade das trocas (coletivas ou individuais) em atitudes de filantropia, em uma generosidade gratuita. Nessa rede de solidariedade existia uma relação de poder relacionada à dependência do outro igual, já que não havia a presença do poder público nem para assistir tão pouco para estabelecer regras. Do mesmo modo que a partilha era uma grande recurso de sobrevivência em um ambiente de escassez, era também na regulação dessa comunhão que se estabeleciam as sanções. Ou seja, as sanções são baseadas tanto nas vantagens da comunhão dos escassos recursos como nas habilidades pessoais que serviam a coletividade.

Do mesmo modo que as relações de ajuda mútua era um parâmetro para regras de convivência no universo agrego, também havia os vínculos que reforçavam a solidariedade como múltiplos poderes fragmentados. É o caso das parteiras, que carregavam um respeito e reverência como se fosse um ente familiar. A parteira carregava a representação desse espaço de convivência de solidariedade, do gesto gratuito, prestando seu ofício em um momento de dificuldade, intimidade e consagração. As habilidades pessoais também pertenciam à vida espiritual, como é o caso da benzedeira e do curador.

O poder se forma e se estabelece internamente pela necessidade de sobrevivência, surgindo a partir da carência, em regras próprias baseadas na manutenção da vida em grupo, mediante a necessidade da coletividade. As sanções se realizavam com base na reciprocidade, na convivência diária. As coerções se sustentavam e eram efetivadas do mesmo modo que se exerciam na convivência da coletividade: no cotidiano e de forma pulverizada, interligadas em redes de relações e poderes que se entrecruzavam. As instituições na sociedade agrega se fundavam nas práticas baseadas na ajuda mútua realizadas no cotidiano, como o "Dar o fresco" e a "Troca do dia".

Das sanções, a mais efetiva era o distanciamento e o impacto que poderia causar em uma possível ausência de colaboração do grupo diante das necessidades pessoais. Em um 
ambiente de extrema carência, ações assim significavam muito. A ameaça ou privações do coletivo são determinantes para a sobrevivência, como aponta o depoimento do entrevistado " $\mathrm{S}$ "

A relação de vizinhança na roça é muito forte. Muito desse sentimento de solidariedade, caridade. Toda vez que se fazia biscoito, tinha de levar para os vizinhos todos. Biscoito, que é uma coisa comum. Se eu faço alguma coisa em minha casa e não compartilho é como se eu estivesse fazendo um desligamento. Fulano tá desligando de nós. Matou um porco e não mandou 'o fresco'. Fez um biscoito, não mandou 'pra' nós. É uma rede de solidariedade.

Aquele que não divide o que produz também deixa de ser beneficiado com o que a comunidade pode compartilhar, inclusive nos micropoderes integrados nessa rede. $\mathrm{O}$ trabalho da parteira não era cobrado. Mas poderia vir a ser a quem não pertencia ou partilhava as regras desse grupo. O entrevistado " $\mathrm{H}$ " cita um caso de uma família que, vivendo mais afastada, foi cobrada pelo trabalho de parto: "O pai me procurou e me pediu '50 conto', porque a filha pariu e [segundo o avô] 'a parteira só sai lá de casa se eu pagar ela"'.

Sendo micropoderes agindo em rede de solidariedades, quem é rezador não ultrapassava as especificidades do seu ofício. Do mesmo modo a parteira. Não havia uma liderança que assumisse os interesses coletivos. A política não se personificava, se realizava em um emaranhado de reciprocidades, existindo um reconhecimento das regras na expectativa da conduta do outro, conduzindo assim comportamentos já estabelecidos. Era no dia-a-dia que estava o potencial limitador, facilitando ou regulando os recursos de poder.

\section{Rito e poder nas comunidades agregas do Mucuri}

Para que se fortaleçam as relações de poder construídas nas comunidades agregas e manter vivas suas instituições, o rito cumpre um papel de reforço fundamental. Em um ambiente onde as regras são construídas de modo pulverizado e as coerções também são determinadas por práticas fragmentadas, do mesmo modo, os rituais não são estabelecidos de modo centralizado e formal como ocorre no modelo político clássico. No ambiente agrego, esses ritos podem ser mais evidenciados nas festividades: "Tinha batuque, tinha roda, tinha 'polista', jogava quadra, jogava verso" (Entrevistado “L”).

Nos eventos, a presença da cultura afro-brasileira no Mucuri era uma constante nas narrativas dos entrevistados: "Aqui tinha umas comunidades de pretos. Eu ia 'pra' lá nas festas todas, Santa Cruz, Ouro Verde. Eu ia pra lá a pé, aquele tempo não tinha transporte, 
10 quilômetros de distância” (Entrevistado “E”). Realidade também confirmada pelo entrevistado "O": "no agrego tinham nos costumes o batuque".

Dessa proximidade entre violão e batuque, nas narrativas do agregado, entre as mais constantes nessas falas foi o "Caboclo". A base do Caboclo era o improviso: "Um jogava o verso e depois outro vinha e respondia. Juntava gente em redor 'pra' acompanhar" (Entrevistado "F"). Como quase tudo nessas comunidades, o fabrico dos instrumentos era feito pelos próprios agregados: “Tocavam com instrumentos que eles mesmos faziam. Inclusive com a viola de cocha. As violas, eles mesmo que faziam de madeira. As caixas eram feitas de couro de boi" (Entrevistado "J").

Geralmente o tema fazia referência a uma pessoa, que poderia ou não estar presente na roda de Caboclo, ironizando aspectos individuais ou fatos ocorridos: "Era uns oito e todos tiravam uma estrofe. Inventava um Caboclo de um morador da comunidade, quem quer que seja” (Entrevistado “A”). Era um tipo de expressão que exigia o pensamento rápido para adequar às rimas: "tinha uns que já te respondia no pé da letra. Tinha um primo que era só dar um toque nas costas ele já virava e te respondia. E se 'agravasse' era pior, que ele te rebatia" (Entrevistado "H"). Nos cantos Caboclos, para atingir a pessoa em pauta, eram usadas as expressões locais, animais, ambientes, dentro da própria representação e linguagem do agrego. Geralmente era cantada após a visita de Folia de Reis.

\section{A Folia de Reis nas comunidades agregas do Vale do Mucuri}

O catolicismo tinha papel central na cultura dos agregados. No entanto, praticamente os representantes da Igreja Católica não se faziam presente nas comunidades agregas: “Padre não ia lá" (Entrevistado “Q”). Ou "Padre nunca veio aqui” (Entrevistada “G”). Foi construído sem o corpo presente do clero, ganhando uma fisionomia própria, dentro do próprio ambiente de convivência. No isolamento rural, em um espaço dinâmico e de convivência de diversas culturas, as manifestações adotaram nos rituais católicos expressões autônomas.

O editorial da "A Família" de 07 de janeiro de 1922 é emblemático quanto a essa complexa relação do mundo agrego a partir do olhar da Igreja. O jornal faz duras críticas às festividades católicas realizadas no mundo rural. Segundo o texto, os padres que vão celebrar as festas voltam contando “...coisas do arco da velha”, abusos quanto à fé católica: 
Somas vultosas se gastam em fogos de artifício e música, quando não se desviam esmolas dos fieis para danças, bebidas alcoólicas, roupas de festeiro, etc. Chega-se até a triste e lastimável inconveniência de se noticiar como se fora acontecimento memorável, que na festa se "pandegoa a valer"...vem a propósito recomendar, não deixem profligar os terços viciados por bebidas alcoólicas, jogos ou danças, tão comuns principalmente nos pequenos povoados e casas esparsas fora das paróquias ${ }^{9}$.

Portanto, sem qualquer acompanhamento direto da Igreja Católica na zona rural, diversas eram as festividades e os encontros cristãos assumidos de forma autônoma pela comunidade agrega. Os ritos católicos adquiriam maior vigor com as festividades, que se alternavam de acordo com as datas comemorativas ao longo de todo ano. Desses acontecimentos religiosos citados, a unanimidade é a Folia de Reis.

A Folia de Reis tem origem europeia e faz referência à visita dos reis magos a Jesus Cristo no período de seu nascimento. Chegou ao Brasil pelos portugueses. A festividade inicia em 24 de agosto, data considerada como o nascimento de Jesus Cristo, e finda em 06 de dezembro. Provavelmente a Folia de Reis chegou ao Mucuri junto com a ocupação do século XIX, rito muito presente na cultura do Vale do Jequitinhonha: “A Folia era uma tradição, meu pai era folião, já nasci com a Folia. Eu era pequenininho, e nem sei quando começou” (Entrevistado “Q”).

O rito, mesmo com suas diferenças locais, seguia certas liturgias que não alteravam: "Ia de casa em casa cantando. Saia no mundo, cantando nas casas" (Entrevistado "N"). O cantar, o alternar as visitas, o hábito noturno, aspectos presentes invariavelmente nos relatos: "Vinham para minha casa, cantavam, saiam caladinhos 'pra' casa do outro. Daqui ia para casa do vizinho, cantavam, daí para outro vizinho, até amanhecer o dia. Eles andavam a noite toda" (Entrevistado "E”).

A vestimenta usada pelos foliões, quando os recursos possibilitavam, era de cor vermelha: "A Viola toda enfeitada de vermelho, e os tocadores também todos enfeitados de vermelho" (Entrevistado "F"). Havia quem tomava frente da cantoria e os instrumentos que acompanhavam eram de acordo com as possibilidades. Mas a base era violão, pandeiro e percussão: "Era viola, caixa e pandeiro, tudo feito em casa" (Entrevistado "D").

$\mathrm{O}$ rito da Folia não se limitava aos cantos religiosos. O que viria depois da Folia, ritmos, danças e músicas, dependia das raízes culturais da comunidade: “Tinha a saudação. Eles cantavam a Folia, a louvação ao presépio e depois vinha a batucada. Era batucada, dança, jogada de verso. Era de descendência de preto, porque o que mais se

\footnotetext{
${ }^{9}$ Jornal A Família - 07.01.1910 - p. 02.
} 
escuta são os tamborzinhos" (Entrevistado "N"). E, nos depoimentos, a forte influência da cultura negra: "Cantou Folia de Reis, falou dos batuques que havia depois da Folia" (Entrevistado "H"). Mas era o Canto do Caboclo que, geralmente, sucedia os cantos religiosos da Folia: "Era muito forte a Folia de Reis. Ia de casa em casa cantando. Depois tinha o Caboclo" (Entrevistado "R").

A chegada em cada casa não era previamente marcada: "Cantava do lado de fora e o povo acordava lá dentro" (Entrevistado "N"). "As pessoas sabiam que era tradição de todo ano, que qualquer hora podia chegar, já ficavam esperando de sobreaviso. Dormindo, ouvia a batida da viola, o povo levantava doido" (Entrevistado "Q"). A Folia visitava uma casa, em seguida ia para outra: "Numa noite fazia cinco a seis casas" (Entrevistado "Q"). Os foliões tinham a noção geográfica do espaço de convivência, sabiam previamente do percurso a ser realizado naquela noite. Especialmente para programar o local que iriam descansar no final de cada jornada noturna.

Tocar e cantar todas as noites quase duas semanas exigia descanso e os foliões o faziam durante o dia. Alguns retornavam para própria casa, mas em grande parte dos depoimentos, não: "Eles andam a noite inteirinha, e onde amanhecer o dia eles ficam em uma casa, repousava no dia" (Entrevistado "L"). Não retornar para casa se justificava, pois a Folia percorria grandes distâncias, nem sempre se limitava ao espaço de uma só fazenda. Algumas comunidades tinham a moradia próxima umas às outras, mas na maioria dos casos se distanciavam: "Tinha fazenda que só tinha um agregado, aí a Folia ia para outra fazenda" (Entrevistado "Q").

Desse mundo de trabalho que era o agrego, havia o respeito do fazendeiro e da comunidade à devoção e a consequente mudança de hábitos cotidianos ocorridas durante o período da Folia: "Naqueles dias não trabalhavam, eles tinham a devoção daquilo" (Entrevistado "C"). Conforme reforça o entrevistado "Q", o afastamento das atividades na fazenda se justificava, pois "era um período certo de ocupar com a devoção".

As doações, chamada de esmola, faziam parte do ritual da Folia de Reis. Cada família entregava aos Foliões o que podia: “Tem a diferença de cada região, por exemplo, em Pavão [município do Vale do Mucuri], cada casa recolhia um dinheiro, ou um produto, como uma galinha ou um leitão, e no final, juntava tudo e fazia a festa" (Entrevistado “E”). A expressão esmola tem o sentido de pequena doação, pois grande parte das famílias era de parcos recursos. "Tinham os cantadores de Reis, iam de casa em casa. Pegava, 
batia nas portas das casas, pedia esmola, para a festa no dia 06 de janeiro" (Entrevistado "C").

O objetivo da arrecadação recolhida de casa em casa era juntar tudo que foi recebido para o uso no dia 06 de janeiro, quando se fazia a festa dos Santos Reis: "O povo dava muita esmola e quando terminava fazia uma festa” (Entrevistado “O”). Algumas comunidades de melhor recursos davam um pouco mais: "Eles davam as coisas, uns davam leitoa, outros davam carneiro" (Entrevistado "D"). Na própria bandeira tinha o local de guardar o dinheiro: "E na bandeira já tinha um bolsão assim, que era o lugar de colocar dinheiro. Quem não tinha dinheiro dava uma leitoa, um mantimento, feijão. Dava o que tinha” (Entrevistado “Q”).

\section{As representações políticas agregas a partir da Folia de Reis}

Muitos ritos adquiriram, ao longo da formação do Brasil, dimensões nacionais. Mas ganharam características específicas, adequando nos diversos territórios manifestações próprias. Em torno das representações produzidas nesses rituais, também a construção do imaginário regional assume sua especificidade. Esses ritos são formas de representações de poder, pois mobilizam e legitimam comportamentos sociais, estabelecendo limites em espaços de convivência. São carregados de afetos e emoções, não tendo a direção racional típicas de representações como a ideologia. A sacralização de normas, a valorização de determinados comportamentos, a exaltação de símbolos específicos, as liturgias: todos esses elementos são mecanismos para garantir o poder.

Ao mesmo tempo, os ritos também contribuem para fazer visíveis algumas representações, identificando parte do que o agregado imagina como real. O que está se buscando nesse estudo, ao considerar a polissemia e polivalência dos símbolos, são os significados percebidos nos ritos para o reforço do poder nas comunidades agregas do Vale do Mucuri.

O primeiro aspecto a considerar nas festividades é a proximidade entre o profano e o sagrado. O mundo da vida e o mundo divino se confundem e se ligam na mesma reza, na mesma louvação. Pelos depoimentos, não apenas as representações adotavam valores fora do mundo cristão na festa de Folia de Reis ou em qualquer outra festividade católica nas comunidades agregas, mas também os comportamentos e hábitos frequentes no cotidiano não se desassociam do rito. É o caso do uso da cachaça. Dizia o Entrevistado "N" que "ganhava galinha, leitoa, e no dia 06 arrematava, fazia a festa. Com muita cachaça". Cantadores e tocadores levavam a cachaça, em um rito que não separava o profano e o 
sagrado: "Quase todo lugar tinha cachaça, o folião também carregava uma cachacinha, o dono da casa também servia cachaça. Aqui quase todo mundo tinha cachaça. Era cachaça boa, de cana mesmo" (Entrevistado "E").

A demonstração de fé nas festas sagradas também se ligava a outros eventos fora do mundo religioso, quando junto à comemoração religiosa vem os batuques, o Caboclo: “A Folia e o Caboclo vinham juntos. O Caboclo era cantado no final da bandeira, realizando o improviso, dirigindo versos para os outros" (Entrevistado "R"). No território agrego, não havia instituições demarcadas para determinar as normas da convivência. Os limites são estabelecidos na vivência silenciosa do cotidiano e dentro das relações de espaços privados. Quem dita o comportamento e realiza as punições é a própria comunidade em redes de micro-poderes baseadas na ajuda mútua. Sendo assim, o instituído está no emaranhado do cotidiano, não sacralizado em símbolos e imagens distantes do vivido.

Desse modo, louvar e tomar cachaça, rezar e dançar, são expressões que se complementam, não estabelecendo uma demarcação precisa dos espaços de punir, pois não havia uma instituição visível e formal como existe hoje na sociedade contemporânea. No caso das representações, a política estava na conduta idealizada nas rezas e nos arranjos, sendo que as diferenças resolvidas na própria cantoria. É o caso do Canto do Caboclo.

Aparentemente, o Canto do Caboclo teria a propensão de provocar conflitos, uma vez que são improvisos que descrevem comportamentos e atitudes de modo crítico em relação ao outro. Em uma roda de homens, sempre armados, a tendência era de resultar em brigas. No entanto, “...o povo festejava. Nunca vi um acidente de ninguém matar ninguém. E nem brigava. E o povo andava armado" (Entrevistado "C").

A análise a ser feita é que o Canto do Caboclo estabelecia no seu improviso os limites individuais de cada membro do grupo. Concomitante, representava diante do poder exercido em uma convivência coletiva, a força decisória da comunidade. O caboclo pertencia a um rito de consagração ao coletivo, no qual o aspecto individual era negligenciado: "A pessoa que recebia o verso não ficava ofendido, era tudo brincadeira" (Entrevistado "E”). Ainda que exposto, o ofendido aceitava o Caboclo: "Cada um com um facão na cintura, mas ninguém nunca brigou. Ninguém também nunca desgostou porque foi inventado um Caboclo dele" (Entrevistado "N").

O Caboclo assumia o papel de resolver desavenças, um tribunal de julgamento conciliador no qual as intrigas eram abrandadas e superadas a partir do canto: 
Em uma ocasião um deu um tapa no outro, saiu rolando na ribanceira. Passado uns dias fizeram o Caboclo: "Vou contar pra você/um fato que aconteceu no coqueiro/na casa de Anália fizeram uma brincadeira/foi uma confusão/fizeram uma desgraceira/Davi saiu rolando/vamos embora, meus companheiros". Essas festividades reforçavam a amizade, voltava naqueles que tiveram a diferença. Na época da Folia, do Caboclo, acabavam as diferenças, virava brincadeira (Entrevistado "Q").

Era através do ritual do Canto do Caboclo que o poder decisório do coletivo, próprio das comunidades agregas, se tornava visível. No improviso cantado, no qual o atrito acabava em graça, estava a decisão do grupo, ou seja, a superação da desavença:

Tinha um fuxico, por exemplo, de "alguém falar de alguém”. Quando era dia de Folia, podia esperar, alguém ia puxar um Caboclo daquele fato, daquele fuxico. Isso acabava em graça. Tudo isso acontecia depois da Folia, quando fazia o café e depois do café. Por isso demorava nas casas (Entrevistado "P”).

O que deixa claro nesse ambiente é que as festividades mundanas não faziam contraposição aos ritos religiosos, elas se interagiam e se complementavam. Ambas eram rituais de reforço do poder nas relações entre agregados, estabelecendo representações que legitimavam as normas fundadas na ajuda mútua. Nesse aspecto, a realidade da comunidade agrega encontrou na Folia de Reis uma grande proximidade com um princípio essencial do catolicismo: a caridade.

A caridade representa uma virtude segundo os valores da Igreja Católica. Conforme já foi tratado anteriormente, a base das relações de poder entre os agregados se formou através de redes de solidariedade e de ajuda coletiva recíprocas diante das necessidades cotidianas, quer sejam materiais, quer sejam espirituais. A Folia de Reis carregava com todos os seus louvores o reforço desse poder coletivo no agrego, que em momentos de escassez ou fragilidades pode contar com os outros da comunidade. Assim, apesar das bases cristãs, o Imaginário Social na Folia adquire feições políticas próprias entre as comunidades de agregados do Mucuri.

Todos os entrevistados foram unânimes e enfáticos em afirmar nos depoimentos que a relação entre os agregados era de harmonia e dependência mútua. A Folia de Reis, nas comunidades agregas, adequou o conceito de caridade cristã a suas vivências. Na ausência completa do Estado, na convivência onde o espaço é privado, as relações se deram pela cooperação, nas reciprocidades individuais ou familiares, daí a presença de ritos que possam amparar essa prática.

Assim, nas comunidades agregas do Vale do Mucuri, a Folia simbolizou a continuidade das relações de cooperação, o reforço das alianças baseadas na ajuda mútua. A caridade da Folia tinha o significado do compartilhamento de bens, materiais ou espirituais, fundamental para a sobrevivência de pessoas que viviam em escassez. Ora, as 
normas, o estabelecimento dos limites de convivência, a regulação dos comportamentos, enfim, as relações de poder no território agrego se fundavam na reciprocidade e ajuda mútua. Seriam essas condutas as referências para as representações políticas, reforçadas através das liturgias da Folia.

Essas representações podem ser identificadas nas atitudes e expressões dos agentes participantes ao longo de todas as etapas da Folia de Reis. A chegada dos foliões às moradas simboliza o primeiro momento de receptividade ao rito. As letras das músicas cantadas ainda na entrada tratam da recepção dos familiares aos foliões. Estar de portas abertas simboliza a predisposição da acolhida a tudo que a cerimônia representa: "Essa era uma que meu pai cantava: 'Porta aberta e luz acesa/recebei com alegria/Recebei Divino Deus, São José e Santa Maria"” (Entrevistado “Q”). O anúncio da chegada, sendo um rito essencialmente patriarcal, é para o homem da casa: "Senhor, o dono da casa/senhor o dono da casa/Põe a mão no travesseiro/Põe a mão no travesseiro/Acorda sua família/Acorda sua família/Quem 'tá' no sono primeiro/Quem 'tá' no sono primeiro" (Entrevistado “Q”).

Importante ressaltar que a sacralização ocorre no espaço privado. $\mathrm{Na}$ ausência de ambientes públicos, a casa é louvada. A tradicional Calix bento adapta a letra a essa realidade: "Deus te salve, casa santa/Deus te salve, casa santa/Onde Deus fez a morada/Onde Deus fez a morada. Onde mora o calixbento/onde mora o calixbento/e a hóstia consagrada, ô , ai” (Entrevistado "Q").

$\mathrm{O}$ início da Folia era, nessas comunidades, invariavelmente à noite, horário incomum de visitas no meio rural: "Tinha um negócio de falar que Folia andava de noite, mas não era criminoso" (Entrevistado "B"). Certamente era um turno onde se encontrava toda a família em casa, mas seu significado transcende à praticidade. Simboliza a disponibilidade em acolher e ajudar em qualquer ocasião de necessidade, quer seja em momentos de extrema dificuldade, quer seja em ocasiões do cotidiano.

Assim, receber a Folia de modo incondicional sinalizava a disposição extrema para socorrer o vizinho nos momentos de privações. Representava que a família estava aberta tanto para partilhar as alegrias do nascimento quanto para auxiliar nos duros golpes da morte. A correria da parteira para a nova vida que chega ou o atendimento a quem foi picado de cobra.

Passado o primeiro momento, o de receber a Folia, iniciava o segundo momento: 'Eram dois momentos da folia. Um 'pra' cantar, 'pra' abrir a porta, a outra era 'pra' 
cantar, "pra' pedir esmola" (Entrevistado "Q"). Na continuidade dada ao sentido da partilha, a casa deveria doar algo à Folia: "A temática da Folia era a caridade, inclusive no final da Folia pede esmola. Quando a pessoa chegava na casa ela estava pronta para receber alguma coisa”( Entrevistado “Q”). A doação recebia nas louvações o nome de esmola: "Santo Reis, tem uma esmola..." (Entrevistado "M").

Nesse aspecto, a esmola não significa, na Folia, a entrega de quem tinha posses a quem estava na pobreza, típico do catolicismo, mas no sentido de simbolizar a partilha de uma vivência em comum. $\mathrm{O}$ ato significava a mão dupla do receber e entregar, dentro de um dos elementos que determinavam o poder no agrego, que seria a reciprocidade, inclusive espiritual: "A tradição da Folia passava a ideia de muita solidariedade e caridade. Meu pai dizia que a cada vaca que ele comia, levava a vida inteira. Qualquer coisa que era doada, a pessoa também recebia" (Entrevistado “Q”).

Portanto, há uma leitura própria do sentido dado à caridade existente no mundo cristão. A caridade, iniciada com o que no agrego era chamada de esmola, simboliza a uma cadeia de movimentos que envolve toda a comunidade. A eficiência do ritual era validada na medida em que a comunidade agrega era receptiva às liturgias da Folia de Reis. Desde a recepção em casa até seu ponto máximo no dia 06 de janeiro havia uma cumplicidade dos atores reconhecendo como legítimos os ritos.

Na continuidade do rito, a culminância era a festa dos Santos Reis, no dia 06 de janeiro. Tudo que foi arrecado era usado para essa festividade, que ocorria na casa do devoto da bandeira. Esse ato também carregava significados importantes para o reforço do poder da comunidade agrega. Se nas visitas houve a doação, a entrega, agora era o momento da recompensa, de receber em troca o que foi dado. "O final da Folia de Reis é uma grande confraternização no dia 06 de janeiro. O espírito de ajudar é compensado" (Entrevistado "P").

$\mathrm{O}$ ato de doar para a comunidade e receber de volta o que foi entregue também remete a outro elemento fundamental na construção do Imaginário Social dessas comunidades agregas do Mucuri, que é a continuidade das solidariedades e o sonho de um futuro de farturas. A chegada dos foliões nas casas trazia o canto do ano novo, esperanças renovadas: "Boa noite, meu senhor/Aqui chegamos cantando/são véspera de festa/entrada de novo ano/entrada do novo ano, ai, ai..." (Entrevistado "D").

Ocorrendo no espaço privado, o apogeu da festa de Folia de Reis carregava para o imaginário da comunidade também a forte relação entre a fartura e a comunhão: " $O$ povo dava muita esmola e quando terminava fazia uma festa. O dono da Folia fazia a 
festa na casa dele. Era cachaça, comida, pão, biscoito" (Entrevistado “O”). Apolinário sintetiza em sua fala o conjunto de todo o ritual realizado da Folia de Reis:

\footnotetext{
Pegava, batia nas portas das casas, pedia esmola, para a festa no dia 06 de janeiro. Aí rezava o terço. O dinheiro recolhido gastava 'pra' comprar cachaça, fazer biscoito, fazer bolo. O terço era rezado no dito que fez a promessa pra tocar na Folia. Ele tinha a promessa 'pra' sair nas casas e rezar o terço no dia de Reis, dia 06. Aí era a noite toda rezando, cantando, comendo e tomando cachaça (Entrevistado "C").
}

Estabelece, dentro da realidade própria do agrego, suas regras a partir dessa conexão de liturgias e símbolos durante a Folia de Reis. No rito há o reforço do Imaginário Social sacralizando a partilha, a reciprocidade na ajuda em um ambiente de escassez, ao mesmo tempo em que reforça as relações de poder a partir desses princípios.

Não participar da vida em partilha e afastar dos seus ritos implicava em perder toda a relação dessas redes construídas nas comunidades agregas. Nos depoimentos, é possível notar que as famílias que apresentavam situações mais precárias mais extremas eram as mais distantes da comunidade e das festividades, não comungavam com os ritos de reforço e benefícios da partilha coletiva. A cantiga já reproduzida reforça esse princípio: "Caninha Verde/Ô minha verde caninha/Se você não vir na minha casa/eu também não vou na sua" (Entrevistado “Q”).

O Entrevistado "H" apresentou sua trajetória no agrego de extrema carência, mas, de acordo com suas palavras, também tinha grande distanciamento das festividades da comunidade: "A região aqui sempre foi fraca na Folia de Reis. A festa de Caboclo aqui também era difícil. Violeiro aqui na região não existia" (Entrevistado "H”). No entanto, segundo o depoimento de Entrevistado "C", muito próximo da morada do Entrevistado "H", no Tatu Assado [comunidade do município de Teófilo Otoni] tinha um ambiente festivo, inclusive a existência da Folia de Reis “...até poucos anos”. Estando longe da convivência com os vizinhos e ignorando os ritos, era também privado das partilhas que a comunidade poderia oferecer.

\section{Considerações finais}

Ter o Estado como referência única traz enormes dificuldades para o entendimento da política. As regras dessas convivências formadas à margem do poder público, caso do agrego, se tornam perceptíveis através de instituições que funcionam de forma autônoma e, em alguns contextos, independente ou fragilmente reguladas pelo Estado (apesar de 
não necessariamente confrontando com ele, podendo integrar esses limites de convivências específicos de uma comunidade ao Estado).

Analisando os grupos de despossuídos do agrego, está se considerando que existe uma forma de poder construída paralela ao mando da fazenda e às margens do Estado. Eram, para o poder público, comunidades completamente invisíveis. Nesse caso, o poder se tornou um instrumento social para ser utilizado como um mecanismo de manutenção da vida entre iguais. Nesse território onde a vida em comum era realizada em circunstâncias de extrema carência, as relações de poder no agrego se deram através de regras fundadas na partilha e na ajuda mútua. Nesse caso, onde há na coletividade um razoável equilíbrio de forças, se estabelece as bases de convivências fundadas na solidariedade.

As sanções se realizavam nas práticas e vivências do cotidiano, especialmente nas vantagens oferecidas pelas redes de solidariedade do dia-a-dia e é daí que surgem as representações políticas. Esses valores são reforçados em festividades, dentre elas a mais perceptível é a Folia de Reis. A Folia passaria a ser um ritual político de reforço à solidariedade cotidiana entre aqueles que dependem de ajuda mútua diante da escassez, mobilizando e legitimando as regras de convivência a partir da ajuda mútua.

Há a conexão de liturgias e símbolos da Folia de Reis com as regras construídas nas comunidades agregas do Vale do Mucuri. Em um ambiente de escassez, o rito mantém vivo o Imaginário Social, sacralizando a partilha ao mesmo tempo em que reforça as relações de poder a partir desses princípios.

\section{Fonte Primárias}

\section{Periódicos}

“O Norte de Minas”, de 1929 a 1951. Acervo Digital Instituto Histórico e Geográfico do Mucuri.

"A Família”, 1918 a 1925. Centro de Documentação e Arquivos da UFVJM - Campus Mucuri.

"O Mucury", 1899 a 1900. Centro de Documentação e Arquivos da UFVJM - Campus Mucuri.

\section{Entrevistas}

Foram realizadas 20 entrevistas semiestruturadas entre os meses de julho a novembro de 2019, com 05 mulheres e 15 homens, sendo 13 ex-agregados, 04 pequenos proprietários que conviveram com o agrego e 03 grandes proprietários que conviveram com agregados. Foram trabalhadas nesses depoimentos variações regionais, em entrevistas no município de Teófilo Otoni, localizado mais ao centro do Vale do Mucuri, como também em Carlos 
Chagas, ao leste, Poté, a oeste, Ladainha, ao sul, e Águas Formosas, ao norte. Para preservar a identidade dos entrevistados, os nomes foram substituídos por letras do alfabeto.

\section{Fontes Secundárias}

ACHTSCHIN, Márcio. A formação econômica, política, social e cultural do Vale do Mucuri. Teófilo Otoni, 2018.

ASSIS, Flávia Gieseler de Assis. Visões do agregado em Machado de Assis, dissertação de Mestrado apresentada ao Departamento de Sociologia da Universidade de Brasília, Brasília, 2007.

BACZKO, Bronislaw. Imaginação social. In: ROMANO, Ruggiero (org.) Enciclopédia Emandi. V. 5. Lisboa: Imprensa Nacional-casa da Moeda, 1985.

CHARTIER, Roger. A história cultural: entre práticas e representações. Trad. Maria Manuela Galhardo. Lisboa: DIFEL, 1990.

CUNHA, Alexandre Mendes. A diferenciação dos espaços: Um esboço de regionalização para o território mineiro e algumas considerações sobre o redesenho dos espaços econômicos na virada do século. Ouro Preto, Minas Gerais. X Seminário sobre a economia mineira, 2002.

DAMATTA, Roberto. Carnavais, malandros e heróis: para uma sociologia do dilema brasileiro. Rio de Janeiro: Guanabara, 1990.5 ed.

FALCON, Francisco. História e representação. In: CARDOSO, Ciro. F \& MALERBA, J. Representações: contribuição a um debate transdisciplinar. Campinas: Papirus, 2000.

FRANCO, M. S. Carvalho. Homens livres na ordem escravocrata, 2 ed., São Paulo: Ática, 1974.

GIRARDET, Raoul. Mitos e mitologias políticas. Trad. Maria Lúcia Machado. São Paulo: Companhia das Letras, 1987.

KAPLAN, Abraham. LASSWELL, Harold. Poder e Sociedade. Brasília: Editora Universidade de Brasília, 1979.

LAPLANTINE, François. TRINDADE, Liana S. O que é imaginário. p. 24-25. São Paulo: Brasiliense, 1997.

LEBRUN, Gérard. O que é poder. São Paulo: Brasiliense, 2004.

LINHART, Ana Maria Galano Mochcovitch. Êxodo rural, fazendas e desagregação. Estudos Sociedade e Agricultura, 19, outubro, 6-39, 2002.

MACHADO, Cacilda. O patriarcalismo possível: relações de poder em uma região do Brasil escravista em que o trabalho familiar era a norma. R. bras. Est. Pop., São Paulo, v. 23, n. 1, p. 167-186, jan./jun. 2006. 
MARTINS, José de Souza. Os camponeses e a política no Brasil. Petrópolis: Vozes, 1981.

QUEIROZ, Maria Isaura Pereira de. O mandonismo local na vida política brasileira e outros ensaios. S. Paulo: Ed. Alfa-Ômega, 1976.

RIBEIRO, Eduardo Magalhães. Estrada da vida: terra e trabalho nas fronteiras agrícolas do Jequitinhonha e Mucuri, Minas Gerais. Belo Horizonte: Editora UFMG, 2013.

Agregados e fazendas no nordeste de Minas Gerais. Estud. Soc. E Agric., Rio de Janeiro, vol. 18, n. 2, 2010: 393-433.

STOPPINO, Mario. Poder. Dicionário de Política. BOBBIO, Norberto.

MATTEUCCI, Nicola. PASQUINO, Gianfranco. Brasília: Editora Universidade de Brasília, 1998.

SUAREZ, M. Agregados, parceiros e posseiros: a transformação do campesinato no centro-oeste. Anuário antropológico. Fortaleza: edições UFC - Tempo Brasileiro, 1982. 